On the Back Cover:

\title{
WHITMAN TO CURTIS ON TASISTRO: AN UNPUBLISHED LETTER
}

ON 26 APRIL 1872, WhitMAn INSERTED an appeal in the Washington Daily Morning Chronicle for "pecuniary assistance for a man of genius" (Corr 2:173174n). This person was Louis Fitzgerald Tasistro (1808-1886), an Irish-born journalist, actor, State Department translator, and lecturer (NUPM 2:901). Among those who responded to Whitman's appeal was George William Curtis, author and an editor of Harper's Magazine, who gave five dollars. Whitman's letter of thanks to Curtis is now at the Fruitlands Museums and is printed below by permission.

Washington $\mid$ Sunday forenoon. | April 28 [1872].

My dear Mr. Curtis,

Thanks for your kind contribution \& note. The help I seek is for Louis Fitzgerald Tasistro-he has paralysis $-\&$ has had a miserable winter, cold \& hungry-(I have myself been absent great part of the winter)-But he is now up \& comparatively better-your kind $\$ 5$ will truly aid in ameliorating his condition-

Walt Whitman

University of South Carolina

JOEL Myerson 